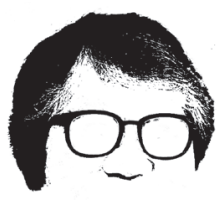

\title{
the Tommy Koh reader
}

Favourite Essays and Lectures 
This page intentionally left blank 


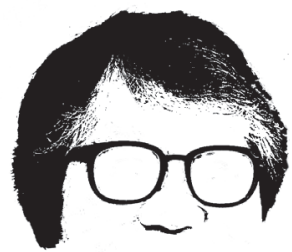

\section{the Tommy Koh reader}

Favourite Essays and Lectures

\section{Tommy Koh}

Ambassador-at-Large, Singapore 
Published by

World Scientific Publishing Co. Pte. Ltd.

5 Toh Tuck Link, Singapore 596224

USA office: 27 Warren Street, Suite 401-402, Hackensack, NJ 07601

UK office: 57 Shelton Street, Covent Garden, London WC2H 9HE

\section{British Library Cataloguing-in-Publication Data}

A catalogue record for this book is available from the British Library.

THE TOMMY KOH READER

Favourite Essays and Lectures

Copyright (C) 2013 by Tommy Koh

All rights reserved.

ISBN 978-981-4571-07-4

ISBN 978-981-4571-08-1 (pbk) 
I wish to dedicate this book to the following men and women who have or had worked with me as my Personal Assistant.

\author{
Faculty of Law, National University of Singapore \\ Mr Young Cheng Wah \\ Mr Lee Cheuk Yen
}

Permanent Mission of Singapore to the United Nations

Ms Ng Chwee Tee

Mr Wilson Teo

Mrs Gloria Elizabeth Monteiro

Ms Soh Geok Lian

Embassy of Singapore, Washington, DC

Mr Subramony

Mrs Jenny Tan

National Arts Council

Ms Soh Guek Keow

Asia-Europe Foundation

Mrs Jenny Tan

Institute of Policy Studies

Ms Mabel Chung

Ms Cynthia Lin

Mrs Jenny Tan

Ms Cecilia Kuek

Ministry of Foreign Affairs

Ms Lily Ng

Ms Wong Fei Joo

Ms Lee Gek Kim 
This page intentionally left blank 


\section{Foreword}

It is a great pleasure and honour to write this foreword for The Tommy Koh Reader, a collection of essays and lectures by one of our most esteemed members in the National University of Singapore (NUS) community, Professor Tommy Koh.

Professor Koh is a well-known figure in Singapore and internationally, having served for many decades as one of our foremost diplomats, and also for his many leading contributions to the development of the arts and culture scene of Singapore. For NUS, he was one of our brightest law students at the inception of the Law Faculty, garnering first-class honours, before going on to complete post-graduate studies in Harvard and Cambridge. He served with distinction as Dean of the Law Faculty from 1971 to 1974. Education remains a powerful passion for Professor Koh, and we are grateful that he has continued his close association with his alma mater, offering his valuable insights and wisdom for new generations of students as Rector of Tembusu College.

Professor Koh has written that he would have happily served out his career as an academic and educator. But fate would have it otherwise, and in 1968, he was asked to serve as our fledging nation's Permanent Representative to the United Nations (1968-1971, 1974-1984). From that point on, he would go forward to establish an illustrious diplomatic career, serving in a succession of high offices, including Ambassador to the US (1984-1990), Special Envoy of the UN (1993), and presently, Ambassador-at-Large.

As a diplomat, he worked tirelessly in service of Singapore, from the crucial period when it had just become a newly independent nation. His writings capture the temper of those years, with its challenges and triumphs, and in particular, he illuminates, as few can, the fortitude and 
courage of our post-independence leadership as they worked relentlessly to carve out the political and economic space for Singapore's survival and growth.

Though he often had to roam far from the shores of our island state, his heart was always firmly rooted in the soil of Singapore. His indefatigable passion, talents and intellect were directed especially, to the fields of arts, culture and heritage preservation - topics which lie especially close to his heart. A well-known patron and supporter of the arts, he was the founding Chairman of the National Arts Council (1991 to 1996), and subsequently, Chairman of the National Heritage Board (2002 to 2011). Working through these institutions, and often through his personal initiatives, he has made immense contributions to promoting and expanding not only the range, but the quality of artistic and cultural opportunities and experiences available to all Singaporeans.

The essays, lectures, and speeches in this collection are thus drawn from a life rich in experience and learning, and are grouped into broad categories: Family, Career, Singapore, Diplomacy, the Law, Art, Culture and Heritage, and finally, Nature and the Environment. These writings reflect Professor's Koh's diverse interests and formidable intellect, and the topics he addresses range from weighty issues such as the rule of law and income disparity, to more lighthearted fare such as Singapore's unique hawker cuisine, botany and even, the naming of roads. He has not hesitated to voice disagreement with prevailing policies or orthodoxies, but always offers his dissenting opinions in good faith, and in a manner intended to encourage greater engagement and understanding. His exposition is clear, forthright and precise; but in his more personal reflections, it is easy to discern the effervescent good humour and warmhearted humanity that has made him a widely admired public figure.

Taken together, this book is much more than a collection of written works and speeches that summarises Professor Koh's career and contributions. We are offered a rare glimpse into the values and beliefs that he holds most dearly, and which have guided his actions and undertakings in his long and distinguished career. For instance, from his mother, he writes touchingly of inheriting her keen eye for aesthetics, good graces 
and zest for vivacious living; from his father, the importance of learning and the joy of reading, but also the need for grit and recovering from hard knocks; and from his formative school years, an acceptance and celebration of diversity and the many hues of our multi-racial society, and an equal intolerance towards ethnic and racial prejudice.

Professor Tommy Koh describes himself amongst these pages as having been "a happy warrior for peace". It is a wonderfully apt phase, as all his efforts have indeed been directed towards the singular objective of creating a better quality of life for all in a safer world. In pursuit of that objective, he has been unsparing and devoted, and the results have been both remarkable and transformative. Yet, throughout his distinguished career, he has always retained a common touch, and an abiding interest and concern for his fellow citizens, particularly those in our society who are less fortunate, or who are more vulnerable. He remains an engaged citizen, and a man of goodwill, modesty and warm generosity.

The world has changed greatly since Professor Koh started out as a young diplomat, but his life and experiences exemplify many crucial traits that have only gained in relevance: a steadfast adherence to principles; an acceptance of diversity and multi-cultural possibilities; a joyful sense of curiosity; and living a purposeful life that impacts positively on society. We would all do well if we could emulate Professor Koh's example of being a tireless advocate for mutual respect, inclusive collaboration and shared advancement.

Professor Tan Chorh Chuan President National University of Singapore 
This page intentionally left blank 


\section{Contents}

Foreword

vii

by Tan Chorh Chuan

1. Family and Friends

A Tribute to My Mother 3

Memories of My Father 5

A Toast to President and Mrs Wee Kim Wee 8

Toasts to President S. R. Nathan on His 80th and

85th Birthdays

Eulogy for S. Rajaratnam $\quad 15$

Eulogy for David Marshall 19

Goh Keng Swee: Ten Lessons from His Life 22

George Yeo: A Man for All Seasons 26

In Defence of Lim Chong Yah 29

A Tribute to Wazir Singh 33

Wang Gungwu: Friend, Mentor and Role Model 34

2. Milestones of Life and Career

What RI Taught Me

41

A Letter from Dean Griswold 44

A Constitution for the Oceans $\quad 50$

Commemoration of the 30th Anniversary of the Opening for Signature of the 1982 UNCLOS 57

Making Peace Between Russia and the Baltics 61

My Cambodian Story $\quad 69$ 
The ASEF Story: The First Three Years

Reflections on the Institute of Policy Studies

Integrating the Business Community in the APEC Process:

Genesis of the Pacific Business Forum

Building a Better World

\section{Singapore}

Lee Kuan Yew's Foreign Policy Legacy

Goh Chok Tong's Foreign Policy Legacy

The Singapore of My Dreams

Don't Knock Minimum Wage Yet

Disagreeing with Some Hard Truths

Demystifying the Presidential Office

In Praise of Older Workers

Opening Eyes to Guide Dogs for the Blind

Should Petain Road be Renamed?

What Singapore Can Learn from Europe

Reflections on Immigration

Are Singaporeans a Kind or Unkind People?

How to be Happy

Singapore's Foreign Policy: Unique Features

7 Habits of a Happy Singaporean

\section{Diplomacy}

The Situation in Grenada

De Tocqueville Revisited: American Politics Viewed from a Foreign Perspective

Why the US Will Still be No. 1 in 2039

Can Any Country Afford a Moral Foreign Policy?

Size Is Not Destiny

Eight Lessons on Negotiations

The Art of Chairing Conferences: Lessons Learnt 238

Two Financial Crises: Five Truths from Asia 245

Australia Must Respect Asean's Role 
In Defence of Europe

China and the World

Japan's Prospects and Challenges: A View from

Southeast Asia

China and Japan: Frenemies?

My Faith in India

China and India: Chini Hindi Bhai Bhai?

The ICRC at 150: Reflections of an

5. Law

Reflections on the Negotiating Process of UNCLOS

The Quest for a World Order

Will There be a Clash of Cultures Between the US and

East Asia?

My Adventure with International Law

The Negotiating Process of the ASEAN Charter

Advice to Law Freshmen

WTO Dispute Settlement System:

Some Reflections

Is There a Role for Law in a World Ruled

by Power?

Mapping Out Rival Claims to the South China Sea

A Tribute to Lee A. Sheridan

A Tribute to Punch Coomaraswamy

A Heartfelt Tribute to a Remarkable Man:

Chan Sek Keong

A Tribute to Satya Nandan

6. Art, Culture and Heritage

10 Stops Along a Singapore Historical Trail

Karel van Kleef: The Man Who Loved Singapore

Tributes to José Rizal and Emilio Aguinaldo 
The Artist, the State and the Market

The Joy of Collecting

A Tribute to Ong Kim Seng

A Tribute to Lee Hock Moh

A Tribute to Kuo Pao Kun

A Tribute to Tan Swie Hian

A Tribute to Earl Lu

A Tribute to Anthony Poon 468

A Tribute to Goh Choo San

A Tribute to Pak Neka

A Tribute to Iskandar Jalil

A Tribute to Joanna Wong

7. Nature and the Environment

The Earth Summit's Negotiating Process: Some

Reflections on the Art and Science of Negotiation

483

The Trees of Singapore

Biodiversity and Cities

Green Thoughts Inspired by Stockholm and Rio

The Future of Water Today

Timeline

Annex I: Books Published

Annex II: Awards by Singapore Government and Agencies 